\title{
Polylobatispora setulosa, a new freshwater hyphomycete from Ilhabela, Sao Paulo state, Brazil
}

\author{
Moro LB ${ }^{1}$, Delgado $G^{2}$ and Schoenlein-Crusius IH $^{1}$ \\ ${ }^{1}$ Instituto de Botânica de São Paulo, CEP 04301-902, São Paulo, Brazil. \\ ${ }^{2}$ EMLab P\&K North Phoenix, Phoenix, Arizona, 85027U.S.A.
}

Moro LB, Delgado G, Schoenlein-Crusius IH 2015 - Polylobatispora setulosa, a new freshwater hyphomycete from Ilhabela, Sao Paulo state, Brazil. Mycosphere 6(1), 13-18, Doi 10.5943/mycosphere/6/1/3

\begin{abstract}
Polylobatispora setulosa sp. nov. is described and illustrated from submerged mixed leaf litter samples collected at streams in Ilhabela, São Paulo state, Brazil. The fungus is distinct in having setulae at the tip of the conidial lobes. Acumispora verruculosa, isolated from identical substrate and characterized by the presence of fusiform, acuminate, rostrate, verrucose, 2-septate, hyaline to greenish conidia, is recorded for the third time from the Americas. They are compared with morphologically similar species and identification keys are provided.
\end{abstract}

Keywords - anamorphic fungi - freshwater fungi - systematics - tropical fungi

\section{Introduction}

Among freshwater hyphomycetes, the so called typical aquatic or Ingoldian fungi have been studied extensively in Brazil, mainly in well-preserved areas of the "cerrado" region (SchoenleinCrusius 2002), the Atlantic rainforest of the state of São Paulo (Schoenlein-Crusius \& Grandi, 2003) and also in a few urban waters (Schoenlein-Crusius et al. 2009, 2014). Recently, however, increasing attention has been paid to other groups of freshwater fungi, particularly those hyphomycete genera frequently reported from terrestrial as well as freshwater habitats and known as facultative-aquatic (Goh \& Hyde 1996) or inmigrants (Shearer et al. 2007). While the semi-arid "caatinga" biome in the northeast Brazil has proven to be rich in freshwater fungi (Barbosa \& Gusmão 2011, Barbosa et al. 2013, Carneiro et al. 2012), other poorly studied or unexplored areas are also believed to harbour a high diversity of this group of fungi.

Between the years 2012 and 2013, an extensive survey of freshwater hyphomycetes inhabiting submerged materials was carried out in the islands off the coast of the state of São Paulo, including the island of São Sebastião in the municipality of Ilhabela. Two interesting anamorphic taxa were collected on mixed submerged leaf litter samples. They are morphologically similar to the genera Acumispora and Polylobatispora, but the latter was found distinct enough from previously described species to be considered as a new taxon. Taxonomic descriptions and illustrations are presented here along with identification keys for both genera. 


\section{Materials and Methods}

\section{Sampling and morphology}

Samples of submerged mixed leaf litter (approx. 10g) and local water were collected in sterile polyethylene bottles (about $200 \mathrm{ml}$ ) and brought to the laboratory. The leaves were cut into pieces in approximately $1 \mathrm{~cm}$ diam. and incubated in Petri dishes containing sterile distilled water. They were kept in climatic chambers at around $20^{\circ} \mathrm{C}$ following Ingold (1975). From the seventh day of incubation and for at least one month, slides of leaf fragments were prepared using polyvinyl alcohol lacto glycerol resin as mounting medium (Morton et al.1993). Fungal structures were observed and measured using an Olympus BX50 light microscope and images were taken with a Leica DM LB2 microscope fitted with a Leica DFC 280 camera.

\section{Isolates}

In order to obtain pure cultures of fungi, water droplets containing conidia of the target fungi were captured with a Pasteur pipette and spread over the surface of Malt Extract Agar (MEA) Petri dishes containing Chloramphenicol (final conc. $25 \mathrm{mg} / \mathrm{L}$ ). After $24 \mathrm{~h}$ of incubation in climatic chambers at $21^{\circ} \mathrm{C}$, the reverse side of the dishes was observed using a stereoscope to verify hyphal growth the position of the conidia was marked with a permanent marker pen. Under aseptic conditions and with the aid of a sterile stainless steel needle, the conidia were removed from the surface of the medium, inoculated onto a new MEA Petri dish and incubated under similar conditions. Permanent slides are deposited in the Herbarium "Maria P. Eneyda Kauffmann Fidalgo" (SP) and fungal cultures are deposited in the Fungal Collection of the Instituto de Botânica, São Paulo (CCIBt).

\section{Scanning electron microscopy}

For scanning electron microscopy (SEM), mycelia with conidiophores and conidia grown on MEA were prepared according to the modified method described by Pan et al. (1994) They were fixed overnight in $2.5 \%$ glutaraldehyde in $0.1 \mathrm{M}$ sodium phosphate buffer ( $\mathrm{pH} 7.4)$, washed thoroughly with distilled water, dehydrated through an ethanol series $(10 \%, 40 \%, 60 \%, 80 \%$ and 100\%), each series lasting 30 minutes and dried in silica gel. After preparation, the stubs were covered with double-sided carbon tape, and the specimens were mounted on stubs, sputter-coated with gold, and examined using a PHILIPS XL series XL 20, S/W, 5.21. scanning electron microscope at $10 \mathrm{KV}$.

\section{Taxonomy}

Polylobatispora setulosa L.B. Moro, G. Delgado \&I.H. Schoenlein-Crusius sp. nov Fig. 1-6 MycoBank MB811045

Etymology - Latin, setulosa, provided with setulae.

Colonies on natural substrate inconspicuous. Conidiophores macronematous, septate, hyaline, forked, bottle-shaped, 10.0-25.74 × 1.43-2.5 $\mu \mathrm{m}$. Conidiogenous cells lageniform, enteroblasticphialidic, hyaline to greenish. Conidia hyaline, triangular, 3-lobed, 8.6-14.3 $\mu \mathrm{m}$ diam., with thick dark walls and a hyaline setula at each tip, 5.7-12.87 $\mu \mathrm{m}$ long; with a central, fuscous halo, 5.7-7.0 $\mu \mathrm{m}$ diam.

Teleomorph - unknown.

Material examined - Brazil, São Paulo, Ilhabela, São Sebastião island, "Cachoeira do Gato" stream, on submerged mixed leaf litter, 14 May 2013, L.B. Moro (Holotype: SP445-978).

Note - Pure culture of Polylobatispora setulosa was not possible to obtain.

Acumispora verruculosa Heredia, R.F. Castañeda \& R.M. Arias. Mycotaxon 101: 90, 2007.

Fig. 7-12 

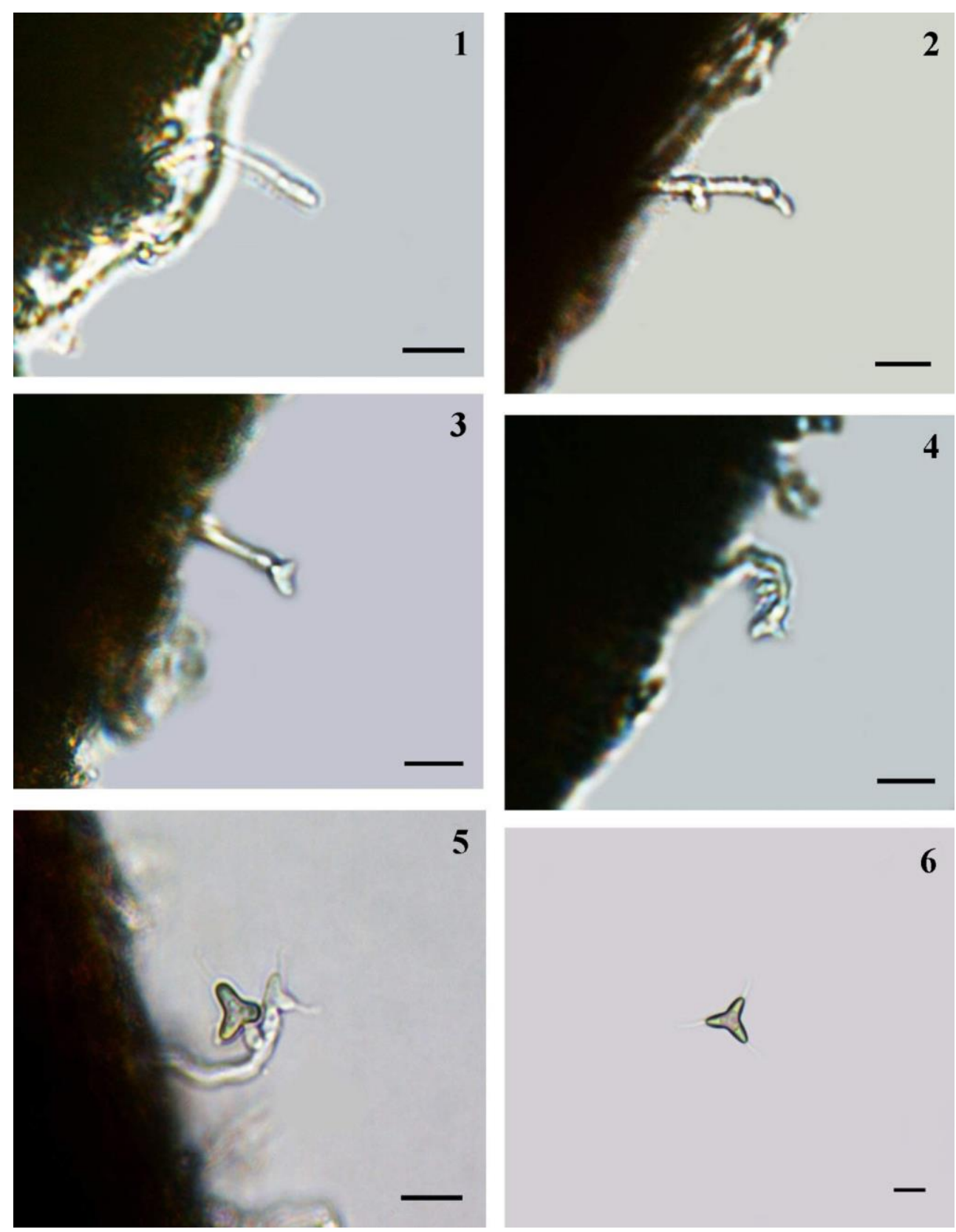

Figs 1-6 - Polylobatispora setulosa. SP 445-978 (holotype). 1-5 Developmental stages of conidiophores and conidia. 6 Mature conidium with setulae at the tip of each lobe and central halo. Scale bar $=10 \mu \mathrm{m}$.

Colonies on MEA dark gray to greenish, velvety, slow growing, reaching less than $2 \mathrm{~cm}$ diam. after 2 weeks of incubation at $21^{\circ} \mathrm{C}$. Mycelium composed of branched, septate, hyaline to pale brown hyphae. Conidiophores macronematous, mononematous, erect, simple or branched, 0 4-septate, light brown to brown, $9.0-51.5 \times 2.86-4.30 \mu \mathrm{m}$. Conidiogenous cells mono- or polyblastic, integrated, terminal and intercalary, proliferating sympodially, denticulate; conidiogenous loci apical or lateral, often protuberant and denticle-like; conidial secession rhexolytic. Conidia fusiform, 2-septate, constricted at the septa, with rounded basal cell and slender apical cell, acuminate, rostrate, hyaline to greenish, 30-45 $(-50) \times 5.0-8.75 \mu \mathrm{m}$, verruculose, with the basal cell often bearing a denticle-like detachment scar.

Teleomorph - unknown.

Material examined - Brazil, São Paulo, Ilhabela, São Sebastião island, "Cachoeira do Gato" stream, on submerged mixed leaf litter, 14 May 2013, L.B. Moro (SP445-979, CCIBt 4066). 


\section{Discussion}

The genus Polylobatispora was originally described from leaves collected in Malaysia (Matsushima 1996) with two species: $P$. deltoidea Matsush., the type species, and $P$. quinquecornuta Matsush., based on the presence of cylindrical or bottle-shaped (doliiform), conidiophores and enteroblastic-phialidic, hyaline, conidiogenous cells that produce single, light brown, stauroconidia with a small scar formed after detachment from the conidiophore. Polylobatispora deltoidea presents characteristic triangular conidia with three lobes and $P$. quinquecornuta 5-lobed conidia. New records of these species are unknown. The main difference between Polylobatispora deltoidea, P. setulosa and P. quinquecornuta is the number of lobes: the first two species possess 3 lobes and the latter 5 lobes. The 3-lobed $P$. setulata differs from $P$. deltoidea by slightly larger conidia and the presence of flexible setulae, one at the tip of each lobe.
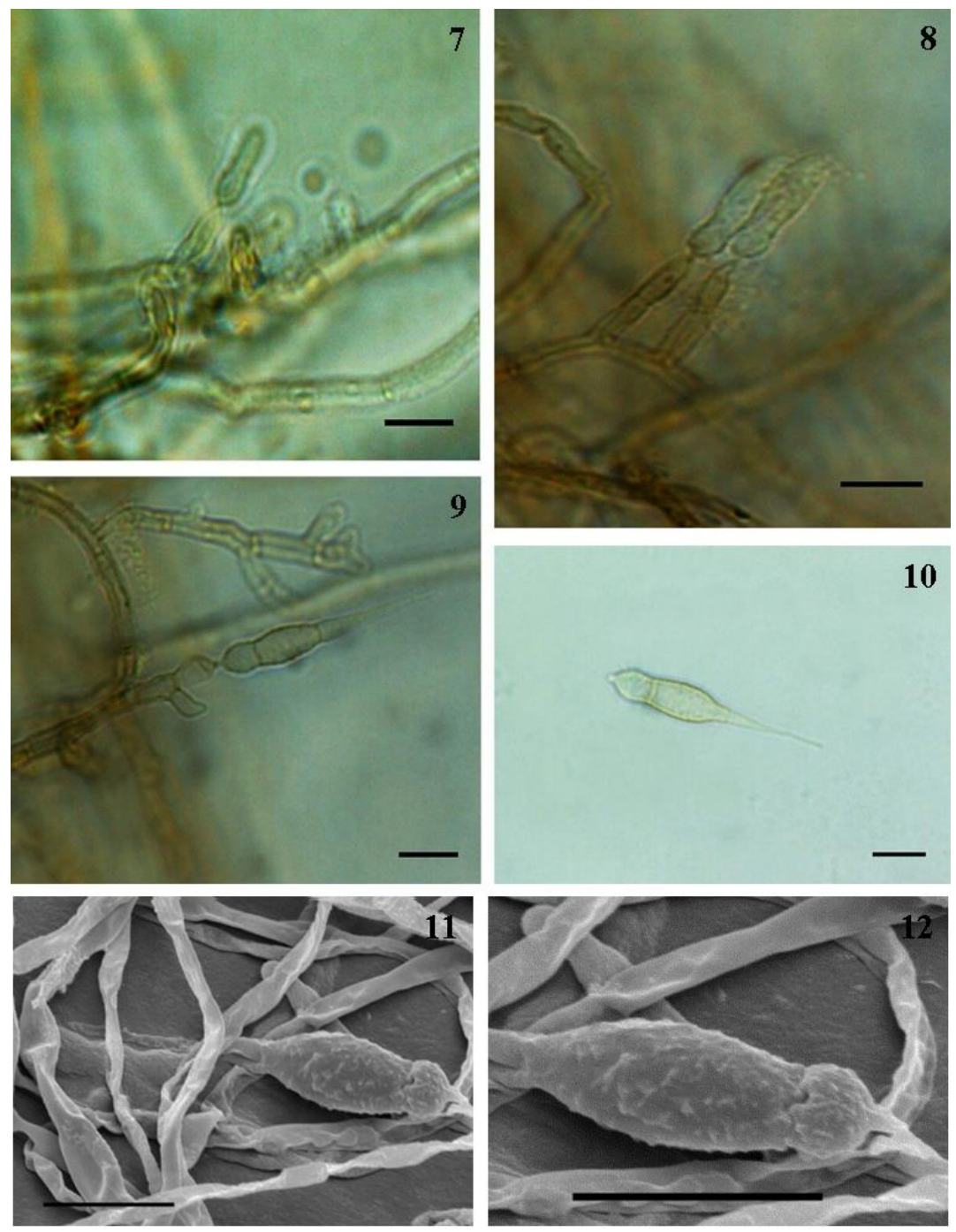

Figs 7-12 - Acumispora verruculosa. 7-9 Conidiophores, conidiogenous cells and conidia. 10 Mature conidium. 11 SEM image of mature conidium. 12 Details of the conidia wall. Scale bar $=$ $10 \mu \mathrm{m}$.

\section{Identification key to species of the genus Polylobatispora}

1a Conidia 5-lobed P. quinquecornuta

1 b Conidia 3-lobed .2

2a Conidia 6-8 $\mu \mathrm{m}$ diam., setulae absent. P. deltoidea

2b Conidia 8.6-14.3 $\mu \mathrm{m}$ diam., setulae present. P.setulosa 
Table 2 Conidial morphology in species of Polylobatispora

\begin{tabular}{lcccl}
\hline \multicolumn{1}{c}{ Species } & Shape & $\begin{array}{c}\text { Diameter } \\
(\mu \mathbf{m})\end{array}$ & $\begin{array}{c}\text { Presencelabsence of } \\
\text { setulae }\end{array}$ & References \\
\cline { 2 - 4 } & 3-lobed & $6-8$ & absent & $\begin{array}{l}\text { Matsushima } \\
(1996)\end{array}$ \\
\hline P. deltoidea & 5-lobed & $11-15$ & absent & $\begin{array}{l}\text { Matsushima } \\
(1996)\end{array}$ \\
\hline P. setulosa & 3-lobed & $8.6-14.3$ & present & this paper \\
\hline
\end{tabular}

Matsushima (1980) described the genus Acumispora to accommodate three species collected on dead leaves in Taiwan: A. uniseptata Matsush., the type species, A. biseptata Matsush., and A. phragmospora Matsush., on the basis of a peculiar acuminate conidial shape and conidia, with different number of septa that secede rhexolytically from monoblastic or polyblastic, sympodially proliferating, denticulate conidiogenous cells on simple or irregularly branched conidiophores. Heredia et al. (2007) described A.verruculosa Heredia, R.F. Castañeda \& R.M. Arias from submerged leaves collected at the waterfall "Los Tuxtlas" in Veracruz, Mexico, with distinctly rough-walled conidia. This fungus was recently reported for the first time from South America on submerged leaves and branches collected in aquatic environments at the urban area of Belém do Pará ("Ilha do Combu", "Parque Ecológico Gunma" and "Parque Estadual do Utinga") located in the Amazon biome (Silva et al. 2013). Our collection is the third from the continent with the conidia slightly larger than in earlier collections indicating that there are variations in conidialsize: earlier collections are 25.4-33.5 $\times 4.4-5.5 \mu \mathrm{m}$ whereas the present collection has conidia measuring 30-45 $\times 5.0-8.75 \mu \mathrm{m}$. Taxonomic key and diagnostic features of described species in Acumispora are given below.

1a. Conidia with verruculose walls

Identification key to species of Acumispora

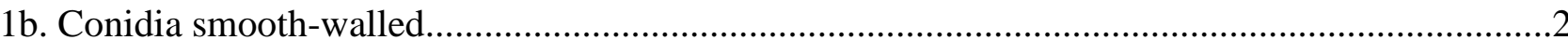

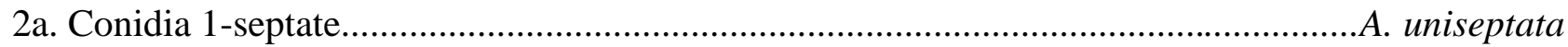

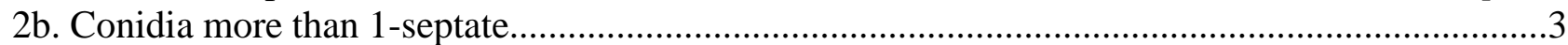

3a. Conidia 3-6 septate.

A. phragmospora

3b. Conidia 2-septate.

A. biseptata

Table 1 Diagnostic characteristics of the genus Acumispora

\begin{tabular}{|c|c|c|c|c|c|c|}
\hline \multirow[b]{2}{*}{ Species } & \multicolumn{5}{|c|}{ Conidia } & \multirow[b]{2}{*}{ References } \\
\hline & $\begin{array}{l}\mathbf{N}^{0} \text { of } \\
\text { septa }\end{array}$ & $\begin{array}{c}\text { Length } \\
(\mu \mathrm{m})\end{array}$ & $\begin{array}{c}\text { Width } \\
(\mu \mathrm{m})\end{array}$ & Color & $\begin{array}{c}\text { Wall } \\
\text { texture }\end{array}$ & \\
\hline A. uniseptata & 1 & $23-28$ & $5.5-6.5$ & $\begin{array}{l}\text { Hyaline to very light } \\
\text { brown }\end{array}$ & smooth & $\begin{array}{l}\text { Matsushima } \\
(1980)\end{array}$ \\
\hline A. biseptata & 2 & $16-25$ & $3.8-5$ & $\begin{array}{l}\text { Hyaline to very light } \\
\text { brown }\end{array}$ & smooth & $\begin{array}{l}\text { Matsushima } \\
(1980)\end{array}$ \\
\hline A. phragmospora & $3-6$ & $20-35$ & $4-5$ & Brown to subhyaline & smooth & $\begin{array}{l}\text { Matsushima } \\
(1980)\end{array}$ \\
\hline A. verruculosa & 2 & $25.4-33.5$ & $4.4-5.5$ & Pale brown & verruculose & $\begin{array}{l}\text { Heredia et al. } \\
(2007)\end{array}$ \\
\hline $\begin{array}{l}\text { A. verruculosa } \\
\text { (present } \\
\text { collection) }\end{array}$ & 2 & $30-45$ & $5.0-8.75$ & Hyaline to greenish & verruculose & This paper \\
\hline
\end{tabular}




\section{Acknowledgments}

The authors are grateful to the director of the Ilhabela State Park and to the Instituto Florestal, Secretaria de Estado do Meio Ambiente de São Paulo, for permission and support during field work and to the Instituto de Botânica, São Paulo, for laboratory facilities. The first author acknowledges CAPES (Coordenação de Aperfeiçoamento de Pessoal de Nível Superior) for the award of a Ph.D. scholarship. The third author thanks the CNPq for the fellowship (CNPq, Process $n^{\circ}$ 304526/20096), and Alex Almeida Alcântara for designing the plates.

\section{References}

Barbosa FR, Gusmão LFP. 2011 - Conidial fungi from the semi-arid Caatinga biome of Brazil. Rare freshwater hyphomycetes and other new records. Mycosphere 2, 475-485.

Barbosa FR, Raja HA, Shearer CA, Gusmão LFP. 2013 - Some freshwater fungi from the Brazilian semi-arid region, including two new species of hyphomycetes. Cryptogamie, Mycologie 34, 243-258.

Carneiro DA, Rodrigues F, Gusmão LFP. 2012 - Alguns fungos conidiais aquáticos-facultativos do bioma Caatinga. Acta Botanica Brasilica 26, 924-932.

Goh TK, Hyde KD. 1996 - Biodiversity of freshwater fungi. Journal of Industrial Microbiology 17, 328-345.

Heredia G, Castañeda RF, Arias RM, Saikawa M, Stadler M. 2007 - Anamorphic fungi from submerged plant material: Acumispora verruculosa sp. nov., Pleurophragmium aquaticum $\mathrm{sp}$. nov. and Pleurophragmium miniumbonatum comb. nov. Mycotaxon 101, 89-97.

Ingold CT. 1975 - An illustrated guide to aquatic and water-borne hyphomycetes (Fungi imperfecti) with notes on their biology. Freshwater Biological Association, Ambleside.

Matsushima T. 1980 - Saprophytic microfungi from Taiwan, part 1. Hyphomycetes. Matsushima Mycological Memoirs1, 1-82.

Matsushima T. 1996 - Matsushima Mycological Memoirs 9, 1-21.

Morton JB, Bentivenga SP, Wheeler WW. 1993 - Germplasm in the International Collection of Arbuscular and Vesicular-arbuscular Mycorrhizal Fungi (INVAM) and procedures for culture development, documentation and storage. Mycotaxon 48, 491-528.

Pan J, Ho HH, Jong SC. 1994 - A scanning electron microscopy study of Phytophthora and Halophytophthora species. Mycotaxon 51, 257-279.

Schoenlein-Crusius IH. 2002 - Aquatic Hyphomycetes from cerrado regions in the state of São Paulo, Brazil. Mycotaxon 81, 457-462.

Schoenlein-Crusius IH, Grandi RAP. 2003 - The diversity of Aquatic Hyphomycetes in South America. Brazilian Journal of Microbiology 34, 183-193.

Schoenlein-Crusius IH, Moreira CG, Bicudo DC. 2009 - Aquatic Hyphomycetes in the Parque Estadual das Fontes do Ipiranga PEFI. Revista Brasileira de Botânica 32, 411-426.

Schoenlein-Crusius IH, Moreira CG, Takahashi JP, Gomes EPC. 2014 - Riqueza dos fungos ingoldianos e aquáticos facultativos no Parque Municipal do Ibirapuera, São Paulo, SP, Brasil. Hoehnea 41, 61-76.

Shearer CA, Descals E, Kohlmeyer B, Kohlmeyer J, Marvanová L, Padgett D, Porter D, Raja HA, Schmit JP, Thorton HA, Voglmayr H. 2007 - Fungal biodiversity in aquatic habitats. Biodiversity and Conservation 16, 49-67.

Silva CR, Monteiro JS, Gusmão LFP. 2013 - Fungos conidiais da Amazônia 5: novos registros para América do Sul e Brasil. Resumo do VII Congresso Brasileiro de Micologia, Belém do Pará. 